\title{
Popularity among Teenage Girls in Adelaide and Shanghai: A Pilot Q-Method Study
}

\author{
Laurence Owens ${ }^{1}$, Huaran Feng'2, Juzhe $\mathrm{Xi}^{2}$ \\ ${ }^{1}$ School of Education, Flinders University, Adelaide, Australia \\ ${ }^{2}$ Department of Applied Psychology, School of Psychology \& Cognitive Science, East China Normal University, \\ Shanghai, China \\ Email: larry.owens@flinders.edu.au
}

Received December 2013

\begin{abstract}
Being popular is of crucial importance to adolescents and particularly to teenage girls. In the past, popularity was measured via sociometric ratings and was seen as being well liked and accepted. In recent years, western researchers have asked teens themselves to express their views of popularity. This has led to a new view of popularity as being publically visible and prestigious and not necessarily well-liked. To investigate teenage girls' perceptions of popularity we utilized $Q$ methodology which is concerned with the scientific study of subjectivity. Our samples were 4014 - 16 year old girls from Adelaide, South Australia, and 5316 - 19 year old girls from Shanghai, China. The South Australian study revealed two factors, the first (reported in this paper) called "pretty girl popularity" was concerned with physical attractiveness and fashionable appearance, and characterized by an anti-authority attitude. In the Shanghai sample, only one dominant factor emerged-it defined popular girls as being even-tempered, sincere, forgiving, outgoing and energetic while unpopular girls were seen as being relationally aggressive and self-centred. The differences between our two samples may be related to the different cultural contexts of Adelaide and Shanghai, the former relating to an individualistic ethic and the latter concerned more with social harmony.
\end{abstract}

\section{Keywords}

Popularity, Teenage Girls, Cultural Differences, Q Method

\section{Introduction}

For many years, researchers used sociometry to study popularity among adolescent peer groups [1] [2]. This involved asking participants to nominate up to three peers they would/would not like to be with. Popularity measured in this way resulted in it being defined as peer liking or acceptability. Sociometric popularity was found to be associated with pro-social behaviours such as being cooperative and helpful and not being aggressive or disruptive in class [3] [4]. However, educational sociologists using unstructured interviews and participant observation found that popularity was more about being publically visible and prestigious and that it may not be associated with being well-liked [5]-[8]. Recently social and educational psychologists asked students to say who 
were popular and unpopular rather than well-liked and they found that this public or perceived popularity was similar to the sociological notion of public prominence and social visibility [9] [10]. This more recent way of defining popularity means that popularity may not necessarily be related to being pro-social and well behaved in class. Examining popularity defined by adolescents themselves will enrich the information on peer relationships and deepen our understanding of social interactions among them. Earlier work including our own has suggested that popular girls might also be relationally aggressive to their classmates, creating disharmony in their peer groups [11]-[14]. However, previous studies have generally been conducted in western schools and we do not know if these results will hold, for example, in Chinese schools. This paper reports on data collected via Q sort and follow up interviews in schools in Adelaide, the capital city of South Australia, and Shanghai, the largest east-coast city of China. The aim was to ascertain teenage girls' subjective understandings of popularity in those schools in the two cities of diverse cultural background.

\section{Method}

\subsection{Research Design}

Data were collected by Q method and follow up group and individual interviews. Q method is used to study human subjectivity in a scientifically rigorous way. Firstly, a Q sample of items which represent the concourse of views on a topic of human subjectivity is determined from literature searches and pilot studies with people similar in attributes to the participants in the study. The P sample participants (usually less than 40) are required to sort the Q items on a grid revealing their perspectives on the topic. The views of the participants (rather than the items, as in R factor analysis) are then subjected to factor analysis to reveal underlying commonalities in perspectives [15]-[18].

\subsection{Participants (P Sample)}

The Australian sample consisted of 4014 - 16 year old public school girls (modal age of 15), 18 from a middle class and 22 from a low socio-economic area in Adelaide. The Chinese sample included 5316 - 19 year old (modal age of 18), 21 from a key high school (a proxy for middle class) and 32 from a vocational high school (a proxy for working class) from Shanghai.

\subsection{Q Sample and Procedure}

Separate concourses were determined for each sample. In Adelaide a set of 65 statements on popularity was determined from a search of the literature on popularity and from a series of classroom discussions with adolescents. By examining similarity in items, the concourse was reduced to a manageable Q sample of 35 items for Q sorting. In China the literature on popularity is limited so greater emphasis was given to deriving the $\mathrm{Q}$ sample from classroom discussions. The process eventually resulted in a Q sample of 40 items for the Shanghai study. The participants in both samples ranked each of the items on an inverted grid from +4 , most associated with popularity, to -4 , most associated with unpopularity.

\subsection{Analysis of Data}

PQ method version 2.33 [19] was used to analyse the Q sorts. Inter-correlations between the Q sorts were calculated and a principal components analysis computed. Factors were retained for further analysis if they exceeded an eigen-value of 1.0. The factors were rotated (varimax) and considered statistically significant $(<.01)$ if they exceeded the standard error of a zero order correlation, using the following formula: $2.58(1 / \sqrt{ } \mathrm{N})$ where $\mathrm{N}=$ the number of statements in the Q sample. Q sorts that loaded solely and significantly on one factor were flagged as factor definers [18]. To determine participants' reasons for their Q sort choices, follow up interviews were conducted.

\section{Results}

\subsection{The Adelaide Data}

The factor analysis revealed two main factors (together accounting for $61 \%$ of the variance), the first subscribed 
to by 19 girls (12 out of 18 from the middle class- and 7 out of 22 from the low-income school), and the second supported by 9 girls (all from the low income school). Because of space limitations, only factor 1 will be considered in this paper as it did include students from both schools. For a full description of both factors, see Owens and Duncan [20].

Adelaide Factor 1 "Pretty Girls": The girls named the first factor "pretty girl" popularity and it is made up of selections of items relating to physical and fashionable appearance and being well liked by boys and peers generally (see Figure 1 below which is the composite grid constructed to represent the "best fit" for factor 1). In rank order, they are being very popular with boys, having a lot of friends, being very fashionable, being really pretty, and well-liked by other students. In contrast, based on Z scores $\leq-1$, factor 1 students believe that unpopular girls include (in rank order from most unpopular) those that are very quiet, have special needs, may be lesbian, are well behaved in school, are over-weight, are well liked by teachers, take drugs, and have only one very close friend.

In the follow up interviews, many students discussed the relationship between being popular and being pretty (including not being over-weight) and fashionable. Student 8 (A8) said: "All the popular girls are pretty and skinny and have all the right clothes." A39 explained the link between popularity, appearance and boys: "More opportunity to look better and have a better appearance and be liked by boys more and stuff like that." Items relating to unpopularity such as having special needs and being a lesbian also fit into the physical/fashionable/ liked by boys perspective. In relation to having a lot of friends and being well liked by others, A6 said: "They all know everyone in the school, they know everybody.” A10 said: "They're confident. They know people. With popularity... you'll go to, like, the right parties and you'll know the right people.”

In relation to the pro-school items associated with unpopularity (being well behaved and well-liked by teachers and being quiet), the following transcript material is relevant:

A5: Yea, like on the bus at beach volley ball, they (the popular girls) all sat up the back of the bus and, like, they are really loud and they're not afraid to talk back at all to teachers and stuff.

I: What about in school, do they do all their school work? Do they get along with their teachers?

A10: A lot of them will, like, fight with teachers.

A11: They are fairly smart. They get good grades sometimes. Sometimes they don't do so well coz if you're popular you hold your reputation and you go to parties and you wouldn't exactly do all your school work. You go to parties instead.

\subsection{The Shanghai Data}

A number of rotations were tried but the factors were always inter-correlated so a single un-rotated factor which explained $75 \%$ of the variance was seen as the best solution. All participants from both schools loaded significantly and positively onto it $(p<0.05)$ indicating that all 53 girls' understandings of popularity fell into one perspective-an outgoing pro-social individual who is helpful and caring toward classmates. As for the Adelaide data, PQMethod generated a composite Q sort, indicating the rank order of the 40 items in the factor (see Figure 2). Based on Z-scores $>1$, items most closely associated with popularity in rank order were: is even-tempered, is sincere to others, is forgiving, is outgoing and energetic, is kind to others, helps other students, and has a good sense of humour. Based on Z-scores $<-1$, items most closely associated with being unpopular in rank order were: is double-dealing, sews discord among others, talks about people behind their backs, looks down on others, often shows-off, laughs at other students, considers herself always right, behaves pretentiously, seldom thinks about others, excludes others from the group.

In the follow up interviews, S36 explained being even-tempered and forgiving: "If you make fun of her, she won't be angry or feel that you are laughing at her." Girls also emphasized traits such as being outgoing and energetic, and able to interact with others. S30 reported: "That is to say, when you are with them, you will laugh and chat. They give people an impression of a cheerful one." And S17 said: "We will never be out of a topic when chatting with that popular girl; new topics always pop up." As S20 said: "You will be happy to meet her, and she will pass happiness to you.”

The girls discussed being kind and helpful to others:

S23: If you ask the popular girl a course question that you don't know, she will answer you very patiently no matter what kind of question you ask, unlike someone who is easy to lose patience.

I: So are they excellent in study? 


\begin{tabular}{|c|c|c|c|c|c|c|c|c|}
\hline \multicolumn{3}{|c|}{-4 Most Unpopular } & \multicolumn{3}{|c|}{0 Neutral } & \multicolumn{3}{|c|}{ Most Popular +4} \\
\hline \multirow[t]{7}{*}{$\begin{array}{l}\text { Very quiet } \\
-1.74\end{array}$} & $\begin{array}{l}\text { Has special } \\
\text { needs } \\
-1.68\end{array}$ & $\begin{array}{c}\text { Over-weight } \\
-1.17\end{array}$ & $\begin{array}{l}\text { Good at } \\
\text { school work } \\
-0.99\end{array}$ & $\begin{array}{l}\text { Fights with } \\
\text { other girls } \\
0.40\end{array}$ & $\begin{array}{l}\text { Has tough } \\
\text { friends } \\
0.61\end{array}$ & $\begin{array}{c}\text { Well-liked } \\
\text { by peers } \\
1.27\end{array}$ & $\begin{array}{l}\text { Has a lot of } \\
\text { friends } 1.76\end{array}$ & $\begin{array}{c}\text { Popular with } \\
\text { boys } \\
1.76\end{array}$ \\
\hline & $\begin{array}{c}\text { Is lesbian } \\
-1.37\end{array}$ & $\begin{array}{l}\text { Liked by } \\
\text { teachers } \\
-1.15\end{array}$ & $\begin{array}{l}\text { Smokes } \\
-0.96\end{array}$ & $\begin{array}{c}\text { Physically } \\
\text { matured early } \\
0.37\end{array}$ & $\begin{array}{c}\text { Often in } \\
\text { trouble with } \\
\text { teachers } 0.60\end{array}$ & $\begin{array}{l}\text { Goes out } \\
\text { with older } \\
\text { boys } 0.96\end{array}$ & $\begin{array}{c}\text { Very } \\
\text { fashionable } \\
1.60\end{array}$ & \\
\hline & $\begin{array}{l}\text { Well behaved } \\
\text { in school } \\
-1.25\end{array}$ & $\begin{array}{c}\text { Takes drugs } \\
-1.08\end{array}$ & $\begin{array}{c}\text { Religious } \\
-0.81\end{array}$ & $\begin{array}{l}\text { Good at } \\
\text { sports } \\
0.27\end{array}$ & $\begin{array}{c}\text { Certain } \\
\text { make-up, } \\
\text { hairstyle } 0.52\end{array}$ & $\begin{array}{l}\text { Drinks } \\
\text { alcohol } \\
0.81\end{array}$ & $\begin{array}{c}\text { Really } \\
\text { pretty } \\
1.51\end{array}$ & \\
\hline & & $\begin{array}{l}\text { Has only } 1 \\
\text { close friend } \\
-1.02\end{array}$ & $\begin{array}{c}\text { Lives in a } \\
\text { particular area } \\
\quad-0.60\end{array}$ & $\begin{array}{l}\text { Involved in } \\
\text { scandal } \\
0.13\end{array}$ & $\begin{array}{c}\text { Spreads } \\
\text { rumours } \\
0.49\end{array}$ & $\begin{array}{l}\text { Is quite thin } \\
0.65\end{array}$ & & \\
\hline & & & $\begin{array}{l}\text { Virgin } \\
-0.40\end{array}$ & $\begin{array}{c}\text { From a tough } \\
\text { family } \\
-0.02\end{array}$ & $\begin{array}{c}\text { Very loud } \\
0.49\end{array}$ & & & \\
\hline & & & $\begin{array}{l}\text { White } \\
-0.19\end{array}$ & $\begin{array}{c}\text { Misses school } \\
-0.07\end{array}$ & $\begin{array}{c}\text { Kind to others } \\
0.45\end{array}$ & & & \\
\hline & & & & $\begin{array}{l}\text { Not white } \\
-0.16\end{array}$ & & & & \\
\hline
\end{tabular}

Figure 1. The composite Q sort grid for factor 1 (Adelaide data) (numbers are Z scores).

\begin{tabular}{|c|c|c|c|c|c|c|c|c|}
\hline \multicolumn{3}{|c|}{-4 Most Unpopular } & \multicolumn{3}{|c|}{0 Neutral } & \multicolumn{3}{|c|}{ Most Popular+4 } \\
\hline $\begin{array}{l}\text { Sews discord } \\
\text { among others } \\
-1.47\end{array}$ & $\begin{array}{l}\text { Often shows } \\
\text { off } \\
-1.22\end{array}$ & $\begin{array}{l}\text { Excludes others } \\
\text { from the group } \\
-1.13\end{array}$ & $\begin{array}{c}\text { Usually } \\
\text { against } \\
\text { teachers }-0.46\end{array}$ & $\begin{array}{c}\text { Has special } \\
\text { talents } \\
0.27\end{array}$ & $\begin{array}{l}\text { Has lots of } \\
\text { friends } \\
0.79\end{array}$ & $\begin{array}{l}\text { Helps other } \\
\text { students } \\
1.23\end{array}$ & $\begin{array}{c}\text { Forgiving } \\
1.46\end{array}$ & $\begin{array}{c}\text { Even } \\
\text { tempered } \\
1.66\end{array}$ \\
\hline \multirow[t]{7}{*}{$\begin{array}{l}\text { Double } \\
\text { dealing } \\
-1.71\end{array}$} & $\begin{array}{l}\text { Looks down } \\
\text { on others } \\
-1.30\end{array}$ & $\begin{array}{l}\text { Seldom thinks } \\
\text { of others } \\
-1.15\end{array}$ & $\begin{array}{l}\text { Inflexible } \\
-0.60\end{array}$ & $\begin{array}{l}\text { Pretty } \\
0.25\end{array}$ & $\begin{array}{c}\text { Enjoys herself } \\
\text { while playing } \\
0.73\end{array}$ & $\begin{array}{c}\text { Good sense } \\
\text { of humour } \\
1.20\end{array}$ & $\begin{array}{c}\text { Outgoing and } \\
\text { energetic } \\
1.45\end{array}$ & $\begin{array}{c}\text { Sincere to } \\
\text { others } \\
1.54\end{array}$ \\
\hline & $\begin{array}{l}\text { Talks about } \\
\text { people behind } \\
\text { their backs } \\
-1.46\end{array}$ & $\begin{array}{l}\text { Behaves } \\
\text { pretentiously } \\
-1.19\end{array}$ & $\begin{array}{l}\text { Uses dirty } \\
\text { language } \\
-0.61\end{array}$ & $\begin{array}{c}\text { Liked by } \\
\text { teachers } \\
0.20\end{array}$ & $\begin{array}{c}\text { Good leader } \\
0.69\end{array}$ & $\begin{array}{c}\text { Behaves } \\
\text { naturally } \\
0.99\end{array}$ & $\begin{array}{c}\text { Kind to } \\
\text { others } \\
1.34\end{array}$ & \\
\hline & & $\begin{array}{c}\text { Considers self } \\
\text { always right } \\
-1.21\end{array}$ & $\begin{array}{c}\text { Gossips } \\
\text { a lot } \\
-0.64\end{array}$ & $\begin{array}{l}\text { Is class } \\
\text { monitor } \\
0.20\end{array}$ & $\begin{array}{c}\text { Dresses } \\
\text { neatly } \\
0.49\end{array}$ & $\begin{array}{l}\text { Familiar with } \\
\text { girls' mainstream } \\
\text { culture } 0.84\end{array}$ & & \\
\hline & & $\begin{array}{l}\text { Laughs at other } \\
\text { students } \\
-1.21\end{array}$ & $\begin{array}{c}\text { Unwilling to } \\
\text { interact with } \\
\text { others } \\
-0.75\end{array}$ & $\begin{array}{c}\text { Popular } \\
\text { with boys } \\
0.15\end{array}$ & $\begin{array}{c}\text { Good at } \\
\text { understanding } \\
\text { people's moods } \\
0.47\end{array}$ & $\begin{array}{l}\text { Likes talking } \\
\text { to others } \\
0.80\end{array}$ & & \\
\hline & & & $\begin{array}{c}\text { Gets angry } \\
\text { easily } \\
-0.84\end{array}$ & $\begin{array}{l}\text { Knows how } \\
\text { to bring others } \\
\text { on side } 0.05\end{array}$ & $\begin{array}{l}\text { Gets good } \\
\text { academic } \\
\text { grades } 0.43\end{array}$ & & & \\
\hline & & & & $\begin{array}{c}\text { From affluent } \\
\text { family } 0.04\end{array}$ & & & & \\
\hline & & & & $\begin{array}{c}\text { Shy and } \\
\text { quiet }-0.32\end{array}$ & & & & \\
\hline
\end{tabular}

Figure 2. The composite q sort grid for the un-rotated factor (Shanghai data) (numbers are Z scores).

S23: It depends, you know. Even if she doesn't know the answer, she will friendly tell you "I don't know well about this. I have told you all I know.” 
I: Even if they can't solve the problem, they will be nice to you, right?

S23: Yes, she talks with a smile on her face, and doesn't put on airs. She is cordial. If you are sick, she will ask you if you want to go to hospital or drink water. She cares about you.

In relation to characteristics of being unpopular S41 summed up sewing discord and double-dealing as "speaking ill of her in front of you and speaking ill of you in front of her" As S6 explained, such a girl will be unpopular: "People feel afraid that maybe today she is very close with you but tomorrow or after some time she may speak ill of you in front of others."

A girl will be unpopular if she always considers herself right (rank 34), looks down on others (rank 37), and shows off (rank 36). S25 reported: "For example, a person has got good exam scores and the other one is not so good, and the good one always shows off in front of the bad one, saying your marks are always lower than me." Unpopular girls are seen as self-centred and unwilling to consider others. S23 explained: "Pretentious people think whatever they do is right. If you don't solve their problems, they think it's your fault." S17 said: "Unpopular girls don't pay much attention to others. Sometimes when others are seeking help from them, they will act like that they are annoyed."

\section{Discussion}

In this paper, we reveal differences in teenage girls' constructions of popularity. Essentially the girls from the Adelaide sample have perspectives on popularity which revolve around physical and fashionable appearance, appealing to boys, and a kind of rebellious anti-authority attitude and some risk taking behaviours. The students saw popular peers as exhibiting anti-school attitudes and this can be interpreted as a kind of independence seeking attempt to be "cool" in front of peers.

In the Chinese sample, the perspectives on girls' popularity were quite different. The Shanghai girls saw popular peers as pro-social, friendly and helpful and certainly not aggressive, anti-social or rebellious. In addition there appeared to be no difference in perspectives between girls in the two Shanghai schools, although we are not certain that selection of the two schools actually did result in social class differences as we did not get individual socio-economic demographic data from the participants.

Although our interpretations are tentative, we wonder if the differences found between the western and eastern samples might be due to the different cultural contexts. In China, a collectivist culture based on Confucianism, there is still (despite the influence of the one-child policy) a strong emphasis in parenting, schooling and society generally on social harmony and the common good. Relational aggression and rebelliousness will lead to disharmony so these traits are not appreciated by the teenage girls [21]-[23]. Instead, sincerity, forgivingness and helping others are the traits admired among the Shanghai girls. In western society, the individualistic ethic means that girls might consider what is of direct advantage to themselves and the concept of benefit to the whole group is not at the forefront of the girls' minds. In the Australian sample, rebellious and anti-authority attitudes serve as a declaration of autonomy and are looked up to [20] [24]-[26] whereas in China, the emphasis is more on maintaining harmonious interpersonal relationships and not on rule-breaking and risky behaviours. In the Australian sample, popular girls were seen as pretty and fashionable and attractive to boys. These views were not prominent in the Chinese sample and this could be due to the moral education at home and school with its emphasis on internal qualities rather than physical beauty [22].

In summary, in this paper we have shown the differences between girls' social constructions of popularity in schools in Shanghai and Adelaide. We consider our study exploratory and we suggest some preliminary interpretations of the differences, centred on the contrasting cultural contexts of the samples. Although there is considerable research on peer relationships including aggressive behaviours and popularity in the west, there has been very little work in this area in China. It is fertile ground for further research.

\section{References}

[1] Asher, S.R. and Coie, J.D. (1990) Peer Rejection in Childhood. Cambridge University Press, New York.

[2] Rubin, K.H., Bukowski, W.M. and Parker, J.G. (1998) Peer Interactions, Relationships, and Groups. In: Eisenberg, N., Ed., Handbook of Child Psychology: Vol. 3. Social, Emotional, and Personality Development. 5th Edition, Wiley, New York.

[3] Coie, J.D. and Dodge, K.A. (1983) Continuities and Changes in Children’s Social Status: A Five-Year Longitudinal Study. Merrill-Palmer Quarterly, 29, 261-282. 
[4] Parkhurst, J.T. and Asher, S.R. (1992) Peer Rejection in Middle School: Subgroup Differences in Behavior, Loneliness, and Interpersonal Concerns. Developmental Psychology, 28, 231-241. http://dx.doi.org/10.1037/0012-1649.28.2.231

[5] Adler, P.A. and Adler, P. (1995) Dynamics of Inclusion and Exclusion in Preadolescent Cliques. Social Psychology Quarterly, 58, 145-162. http://dx.doi.org/10.2307/2787039

[6] Adler, P.A. and Adler, P. (1996) Preadolescent Clique Stratification and the Hierarchy of Identity. Sociological Inquiry, 66, 111-142. http://dx.doi.org/10.1111/j.1475-682X.1996.tb00213.x

[7] Eder, D., Evans, C.C. and Parker, S. (1995) School Talk. Gender and Adolescent Culture. Rutgers University Press, New Brunswick.

[8] Merten, D.E. (1997) The Meaning of Meanness: Popularity, Competition, and Conflict among Junior High School Girls. Sociology of Education, 70, 175-191. http://dx.doi.org/10.2307/2673207

[9] De Bruyn, E.H. and Cillessen, A.H.N. (2006) Heterogeneity of Girls' Consensual Popularity: Academic and Interpersonal Behavioral Profiles. Journal of Youth and Adolescence, 35, 435-445. http://dx.doi.org/10.1007/s10964-005-9023-4

[10] Lafontana, K.M. and Cillessen, A.H.N. (2002) Children’s Perceptions of Popular and Unpopular Peers: A Multimethod Assessment. Developmental Psychology, 38, 635-647. http://dx.doi.org/10.1037/0012-1649.38.5.635

[11] Duncan, N. (2004) It's Important to Be Nice, but It’s Nicer to Be Important: Girls, Popularity and Sexual Competition. Sex Education, 4, 137-152. http://dx.doi.org/10.1080/14681810410001678329

[12] Owens, L., Shute, R. \& Slee, P. (2000) "Guess what I just heard!" Indirect aggression among teenage girls in Australia. Aggressive Behavior, 26, 67-83. http://dx.doi.org/10.1002/(SICI)1098-2337(2000)26:1<67::AID-AB6>3.0.CO;2-C

[13] Owens, L., Shute, R. and Slee, P. (2001) Victimization among Teenage Girls. What Can Be Done about Indirect Harassment? In: Juvonen, J. and Graham, S., Eds., School-Based Peer Harassment: The Plight of the Vulnerable and Victimized. Guilford.

[14] Owens, L., Shute, R. and Slee, P. (2000) “I’m in and You're out...” Explanations for Teenage Girls’ Indirect Aggression. Psychology, Evolution \& Gender, 2, 19-46.

[15] Stephenson, W. (1953) The Study of Behavior: Q-Technique and Its Methodology, University of Chicago Press, Chicago.

[16] Brown, S.R. (2003) Q Methodology. In: Lewis-Beck, M.S., Bryman, A. and Futing Liao, T., Eds., The SAGE Encyclopedia of Social Science Research Methods. SAGE Publications, Thousand Oaks.

[17] Brown, S.R. (2008) Q Methodology. In Given, L.M., Ed., The SAGE Encyclopedia of Qualitative Research Methods. Sage, Thousand Oaks. http://dx.doi.org/10.4135/9781412963909.n350

[18] Watts, S. and Stenner, P. (2012) Doing Q Methodological Research. Sage Publications, London.

[19] Schmolck, P. and Atkinson, J. (2013) PQMethod (2.33). Computer Program. http://www.qmethod.org

[20] Owens, L. and Duncan, N. (2009) “Druggies” and “Barbie Dolls”: Popularity among Teenage Girls in Two South Australian Schools. Journal of Human Subjectivity, 7, 39-63.

[21] Li, Y., Wang, M., Wang, C. and Shi, J. (2010) Individualism, Collectivism, and Aggression: Intracultural Variations. Aggressive Behavior, 36, 187-533. http://dx.doi.org/10.1002/ab.20341

[22] Li, Y., Xie, H. and Shi, J. (2012) Chinese and American Children's Perception of Popularity Determinants: Cultural Differences and Behavioral Correlates. International Journal of Behavioral Development, 6, 1-10.

[23] Fujihara, T., Kohyama, T., Andreu, J. and Ramirez, M.J. (1999) Justification of Interpersonal Aggression in Japanese, American and Spanish Students. Aggressive Behavior, 25, 185-195. http://dx.doi.org/10.1002/(SICI)1098-2337(1999)25:3<185::AID-AB3>3.0.CO;2-K

[24] Glendinning, A. and Inglis, D. (1999) Smoking Behaviour in Youth: The Problem of Low Self-Esteem? Journal of Adolescence, 22, 673-682. http://dx.doi.org/10.1006/jado.1999.0262

[25] Corsara, W.A. and Eder, D. (1990) Children’s Peer Cultures. Annual Review of Sociology, 16, 197-220. http://dx.doi.org/10.1146/annurev.so.16.080190.001213

[26] Moffitt, T.E. (2003) Life-Course-Persistent and Adolescence-Limited Antisocial Behavior-A 10-Year Research Review and a Research Agenda. 